\title{
Role of tachykinins in bronchoconstriction induced by intravenous administration of bradykinin in guinea-pigs
}

\author{
C. Kuroiwa*+, E. Umeno*+, H. Nogami*†, S. Kano*+, T. Hirose*†, S. Nishima*+
}

Role of tachykinins in bronchoconstriction induced by intravenous administration of bradykinin in guinea-pigs. C. Kuroiwa, E. Umeno, H. Nogami, S. Kano, T. Hirose, S. Nishima. @ERS Journals Ltd 1996.

ABSTRACT: To elucidate the role of tachykinins in bronchoconstriction induced by intravenous administration of bradykinin (Bk), we studied the effects of FK224, a neurokinin-1 $\left(\mathrm{NK}_{1}\right)$ and neurokinin-2 $\left(\mathrm{NK}_{2}\right)$ receptor antagonist, on the bronchoconstriction induced by intravenous (i.v.) administration of $\mathrm{Bk}\left(5-100 \mu \mathrm{g}^{\mathrm{k}} \mathrm{kg}^{-1}\right)$ in guinea-pigs.

Total pulmonary resistance $(R \mathrm{~L})$ was measured using a pressure-volume sensitive body plethysmograph in anaesthetized artificially ventilated guinea-pigs pretreated with atropine $\left(1 \mathrm{mg} \cdot \mathrm{kg}^{-1}\right)$ and propranolol $\left(1 \mathrm{mg} \cdot \mathrm{kg}^{-1}\right)$.

In the control group, i.v. administration of $\mathrm{Bk}$ produced a dose-dependent increase in $R \mathrm{~L}$. In animals pretreated with FK224, bronchoconstriction induced by higher doses of $\mathrm{Bk}\left(10,50\right.$ and $\left.100 \mu \mathrm{g} \cdot \mathrm{kg}^{-1}\right)$ was significantly reduced, whilst the bronchoconstriction caused by lower doses of BK (5 and $\left.7.5 \mu \mathrm{g} \cdot \mathrm{kg}^{-1}\right)$ was not. Pretreatment with a combination of FK224 and indomethacin markedly inhibited the bronchoconstriction induced by each dose of Bk compared with the groups pretreated with FK224 alone. Although pretreatment with indomethacin alone significantly reduced $\mathrm{RL}$ at a high dose of $\mathrm{Bk}\left(50 \mathrm{\mu g} \cdot \mathrm{kg}^{-1}\right)$, the reduction was significantly lower than that produced by a combination of FK224 and indomethacin.

These results suggest that intravenous administration of a high dose of bradykinin causes bronchoconstriction both by cyclo-oxygenase products and by release of tachykinins.

Eur Respir J., 1996, 9, 741-746.
*Clinical Research Institute, and Depts of +Pediatrics and Internal Medicine, National Minami Fukuoka Chest Hospital, Fukuoka, Japan.

Correspondence: T. Hirose

Clinical Research Institute

National Minami Fukuoka Chest Hospital 4-39-1 Yakatabaru

Minamiku

Fukuoka 815

Japan

Keywords: Bradykinin

bronchoconstriction

intravenous administration

tachykinin release

Received: March 291995

Accepted after revision December 311995

This study was supported by a grant for paediatric research, 3C-03, from the Ministry of Health and Welfare.
Bradykinin (Bk) is a nine amino acid peptide that is produced from high molecular weight kininogen by an enzyme kallikrein (kininogenase), which is contained as an inactive precursor, prekallikrein, in plasma and in various tissues [1], and is involved in inflammatory reactions $[1,2]$. Human lung mast cells contain a kininogenase that is released during allergic reactions [3]. Once bradykinin is formed, it acts locally, as it is rapidly degraded by kininase-I located in the plasma and by angiotensinconverting enzyme (ACE) and neutral endopeptidase in trachea and lungs $[1,4,5]$.

The exact role of bradykinin in bronchial asthma is still uncertain. In asthmatic patients, however, higher kinin concentrations have been observed in plasma and in bronchoalveolar lavage (BAL) fluid after antigen challenge $[6,7]$. It is also known that bradykinin causes constriction of isolated airway smooth muscle in some animal species [4, 8], and also causes bronchoconstriction in asthmatic subjects when given by inhalation [9, $10]$ or by rapid injection intravenously $[11,12]$.

The contribution of tachykinins to bradykinin-induced bronchoconstriction is controversial. It was reported that bradykinin may stimulate vagal afferent $\mathrm{C}$-fibres in dog airways, although bronchoconstriction was not observed [13]. Bradykinin also released tachykinins in perfused guinea-pig lungs and rat trachea [14, 15], and caused constriction of guinea-pig bronchus in vitro [16], although bradykinin-induced contraction was not mediated by tachykinins in ferret tracheal rings in vitro [4]. ICHINOSE et al. [17], in their study using capsaicin, reported that the mechanism of bradykinin-induced bronchoconstriction depended on the route of administration in guinea-pigs. Bradykinin instilled into the airway caused bronchoconstriction through the release of tachykinins, but the bronchoconstriction induced by intravenous administration of bradykinin was not associated with tachykinins. Based on these results, they have speculated that bradykinin is likely to be formed in the airway lumen from high molecular weight kininogens in exuded plasma after release of kininogenase from inflammatory cells, such as mast cells, in bronchial asthma, whilst intravenously administered bradykinin, which is a large molecule, may not diffuse from the circulation as readily.

It is, however, possible that a higher concentration of bradykinin in plasma, especially in severe asthmatic patients [6] would have access to airway C-fibres and release tachykinins before being degraded by ACE in the pulmonary endothelial cells.

SAKAмото et al. [18], in their study using CP-96,345, a nonpeptide $\mathrm{NK}_{1}$ receptor antagonist, reported that the 
bronchoconstriction induced by intravenously administered bradykinin was not associated with activation of $\mathrm{NK}_{1}$ receptors. However, it is not known whether bradykinin-induced bronchoconstriction may involve activation of $\mathrm{NK}_{2}$ receptors rather than $\mathrm{NK}_{1}$ receptors.

The purpose of the present study was to determine whether intravenous administration of bradykinin causes bronchoconstriction by activation of $\mathrm{NK}_{2}$ receptors in guinea-pigs using FK224, a novel tachykinin receptor antagonist, which exhibits selectivity both for $\mathrm{NK}_{1}$ and $\mathrm{NK}_{2}$ receptors $[19,20]$.

\section{Materials and methods}

\section{Anaesthesia and measurement of pulmonary resistance}

Eighty five male Hartley outbred guinea-pigs (Kyudo Co., Saga, Japan) weighing 350-450 g were anaesthetized intraperitoneally with sodium pentobarbital $\left(50 \mathrm{mg} \cdot \mathrm{kg}^{-1}\right)$. All animals were then ventilated with a constant-volume ventilator (Rodent ventilator model 683; Harvard Apparatus, Millis, MA, USA) delivering a tidal volume of 8 $\mathrm{mL} \cdot \mathrm{kg}^{-1}$ at a frequency of 60 breaths $\cdot \mathrm{min}^{-1}$ via a tracheal cannula. A polyethylene catheter was inserted into the left jugular vein for intravascular medications. The animals were then placed in a pressure-volume-sensitive body plethysmograph. Pulmonary resistance $(R \mathrm{~L})$ was measured according to the method of SORKNESS et al. [21]. Briefly, changes in transpulmonary pressure were measured using a Gould P231D transducer (Gould Instruments, Cleveland, OH, USA) connected to the water-filled oesophageal cannula, and tidal airflow was measured with a pneumotachograph (Fleisch No. 0000; Fleisch, Lausanne, Switzerland) coupled to a Validyne MP45-16 differential pressure transducer (Validyne Corp., Northridge, CA, USA). Tidal volume was obtained via electronic integration of the flow signal (Pulmonary Mechanics Analyzer Model 6; Buxco Electronics, Sharon, CT, USA). $R \mathrm{~L}$ signals of pressure and flow signals were monitored on a four-channel chart recorder (Model RTA-1200; Nihon Kohden, Tokyo), and were also used in an analog computer (Pulmonary Mechanics Analyzer Model 6; Buxco) to determine breath-by-breath values for tidal volume, frequency and resistance. $R \mathrm{~L}$ was computed as average values for the entire breath, using a covariance method (Buxco Program 3).

\section{Drugs}

The following drugs were used in the experiments: pentobarbital sodium (Dainippon Pharmaceutical Co., Osaka, Japan), FK224 (Fujisawa Pharmaceutical Co., Osaka, Japan), dimethylsulphoxide, bradykinin and indomethacin (Sigma Chemical Co., St. Louis, MO, USA), atropine sulphate (Tanabe Seiyaku Co., Osaka, Japan), propranolol hydrochloride (Sumitomo Pharmaceuticals, Osaka, Japan).

FK224 (\{N-[N²-[N-[N-[N-[2',3'-didehydro-N-methyl$\mathrm{N}$-[N-[3-(2-pentylphenyl)-propionyl]-L-threonyl]tyrosylL-leucynyl]-D-phenylalanyl-L-allo-threonyl]-L-asparaginyl]L-serine- $v$-lactone $\}$ ) was prepared as a stock solution of $25 \mathrm{mg} \cdot \mathrm{mL}^{-1}$ in dimethylsulphoxide (DMSO).

\section{Pretreatment with FK224 and indomethacin}

All animals were pretreated with atropine $\left(1 \mathrm{mg} \cdot \mathrm{kg}^{-1}\right.$ i.v. ) and propranolol $\left(1 \mathrm{mg} \cdot \mathrm{kg}^{-1}\right.$ i.v. $) 5 \mathrm{~min}$ before $\mathrm{Bk}$ administration. Dose-response curves to intravenous administration of $\mathrm{Bk}\left(5,7.5,10,50\right.$ or $\left.100 \mu \mathrm{g} \cdot \mathrm{kg}^{-1}\right)$ were then constructed with different pretreatments. Animals were divided into four groups: Group 1 was pretreated with DMSO $\left(0.2 \mathrm{~mL} \cdot \mathrm{kg}^{-1}\right.$ i.v., "Control group": $\mathrm{n}=5$ for each dose of Bk); Group 2 with FK224 (5 mg. $\mathrm{kg}^{-1}$ i.v., "FK group": $n=5$ for each dose of Bk); and Group 3 with FK224 and indomethacin $\left(5 \mathrm{mg} \cdot \mathrm{kg}^{-1}\right.$ i.v. for each, "FK and indomethacin group": $n=5$ for each dose of Bk). In Group 4 animals, the same doses of indomethacin and DMSO were also administered before 5 and $50 \mu \mathrm{g} \cdot \mathrm{kg}^{-1}$ of Bk administration $\left(5 \mathrm{mg} \cdot \mathrm{kg}^{-1} i . v\right.$. for indomethacin and $0.2 \mathrm{~mL} \cdot \mathrm{kg}^{-1}$ i.v. for DMSO, "Indomethacin group", $\mathrm{n}=5$ for each dose of $\mathrm{Bk}$ ) to assess the effect of indomethacin alone on the bronchoconstriction induced by lower and higher doses of Bk. DMSO and FK224 were administered $10 \mathrm{~min}$ before and indomethacin $30 \mathrm{~min}$ before injection of Bk. The sequence of addition of drugs, time course and maximal response are shown in figure 1.

\section{Statistical analysis}

$R \mathrm{~L}$ values are expressed as mean \pm SEM. The significance of differences was assessed by Student's unpaired t-test. The difference between groups was considered significant when the p-value was less than 0.05 .

\section{Results}

There were no significant differences in baseline $R \mathrm{~L}$ before $\mathrm{Bk}$ administration between the groups (the mean values of $R \mathrm{~L}$ ranged $0.19-0.22 \mathrm{cmH}_{2} \mathrm{O} \cdot \mathrm{mL}^{-1} \cdot \mathrm{s}$ ) (fig. 1).

Time courses of increase in $R \mathrm{~L}$ using different doses of $\mathrm{Bk}$ are shown in figure 1. Pretreatment with FK224 did not significantly attenuate the increase in $R \mathrm{~L}$ value induced by lower doses of Bk (5 or $\left.7.5 \mu \mathrm{g} \cdot \mathrm{kg}^{-1}\right)$. No significant differences in $R \mathrm{~L}$ between Control group and FK group were observed throughout the experiments. However, the bronchoconstriction induced by higher doses of bradykinin $\left(10,50\right.$ or $\left.100 \mu \mathrm{g} \cdot \mathrm{kg}^{-1}\right)$ was significantly attenuated by pretreatments with FK224. The inhibition by FK224 was particularly evident versus the maximum dose of Bk $\left(100 \mu \mathrm{g} \cdot \mathrm{kg}^{-1}\right)$. The increase in $R \mathrm{~L}$ was significantly attenuated throughout the experiment, as compared to control. On the other hand, pretreatment with a combination of indomethacin and FK224 produced inhibition at all doses. This is clearly illustrated in figure 2, which displays the maximal increase in $R \mathrm{~L}$. In the Control group, the administration of Bk (5-100 $\mu \mathrm{g} \cdot \mathrm{kg}^{-1}$ ) produced a dose-dependent increase in $R \mathrm{~L}$. Pretreatment with FK224 significantly attenuated the increase in $R \mathrm{~L}$ induced by high doses $(10,50$ or 100 $\left.\mu \mathrm{g} \cdot \mathrm{kg}^{-1}\right)$ of bradykinin $(\mathrm{p}<0.05)$. Pretreatment with a combination of indomethacin and FK224 markedly inhibited bradykinin-induced bronchoconstriction compared with the FK group $(\mathrm{p}<0.01)$ at each dose of $\mathrm{Bk}$.

Figure 3 shows the effect of indomethacin on Bkinduced bronchoconstriction. Although the pretreatment 

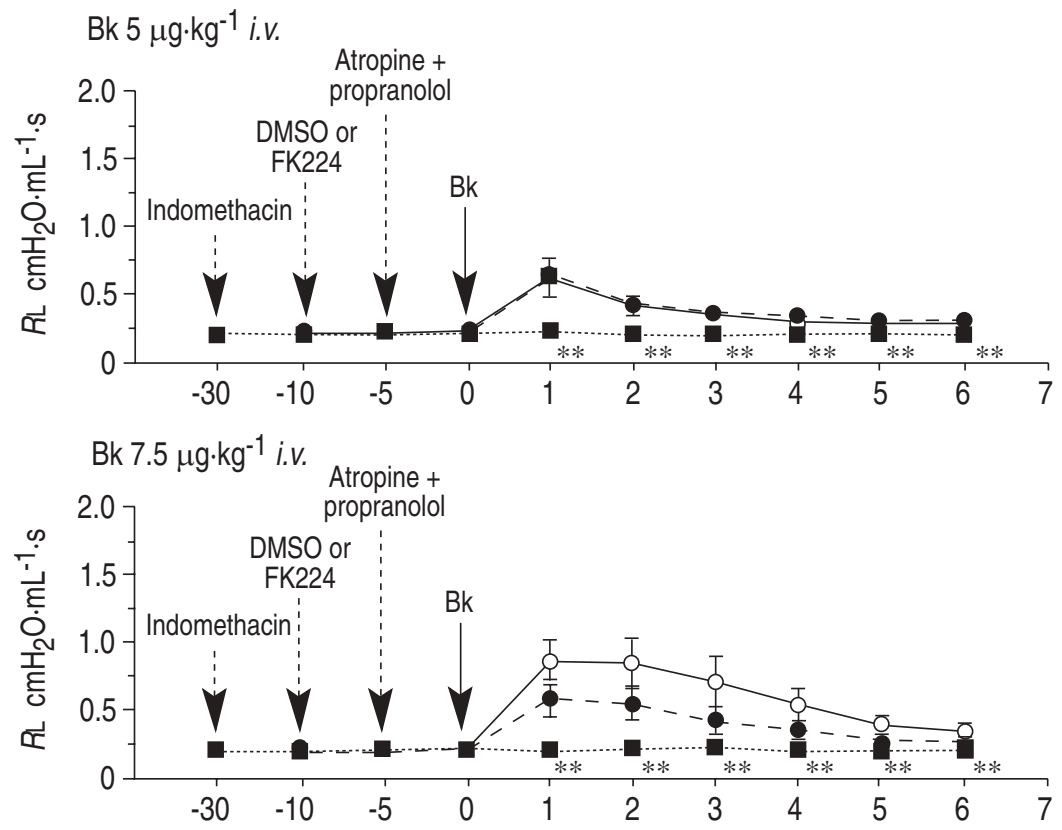

Bk $10 \mu \mathrm{g} \cdot \mathrm{kg}^{-1}$ i.v.

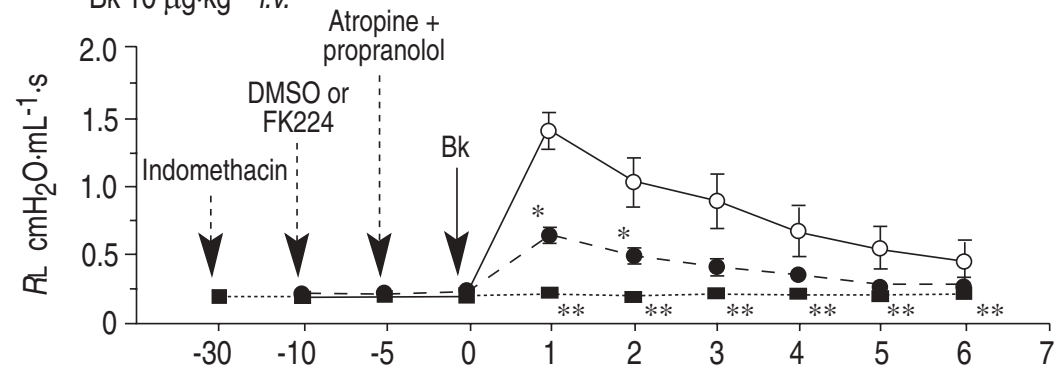

Bk $50 \mu \mathrm{g} \cdot \mathrm{kg}^{-1}$ i.v.

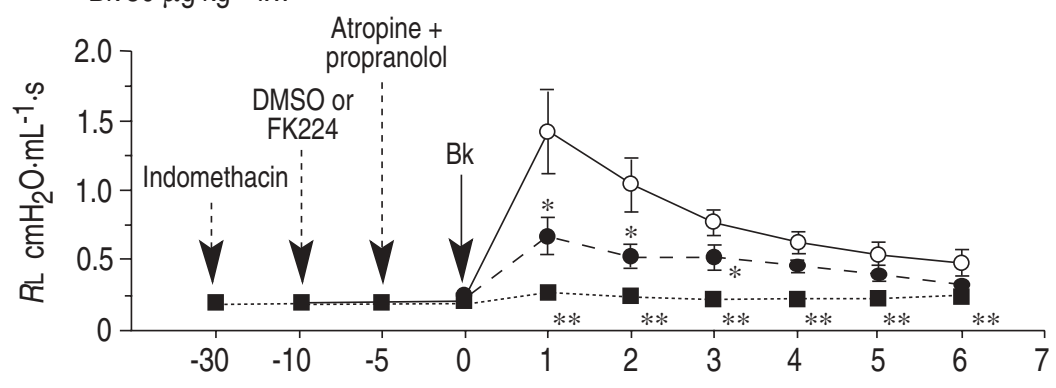

Bk $100 \mu \mathrm{g} \cdot \mathrm{kg}^{-1}$ i.v.

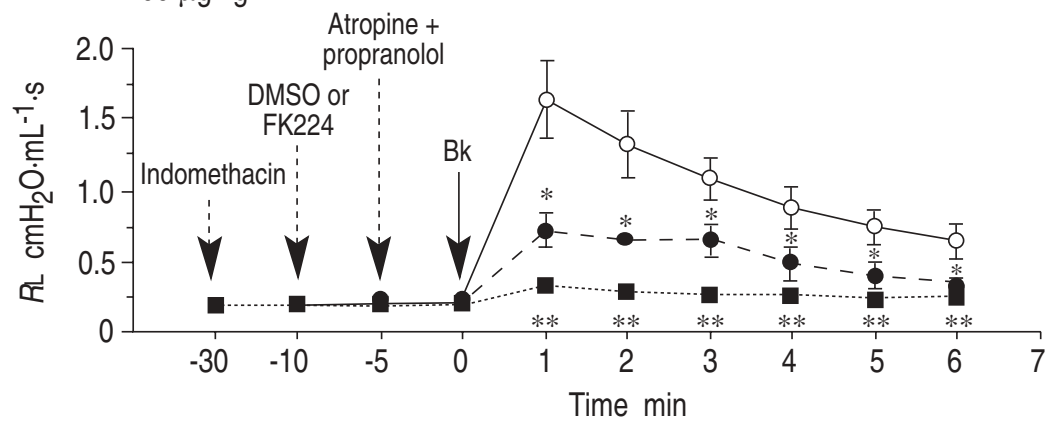

Fig. 1. - Time course of increase in pulmonary resistance $(R \mathrm{~L})$ values after i.v. administration of bradykinin $\left(5-100 \mu \mathrm{g} \cdot \mathrm{kg}^{-1}\right)$ in guinea-pigs. All animals were pretreated with atropine ( $1 \mathrm{mg} \cdot \mathrm{kg}^{-1}$ i.v.) and propranolol $\left(1 \mathrm{mg} \cdot \mathrm{kg}^{-1} i . v\right.$.). Animals pretreated with DMSO (Control group: $0.2 \mathrm{~mL} \cdot \mathrm{kg}^{-1}$ i.v., $\mathrm{n}=5$ ), FK224 (FK group: $5 \mathrm{mg} \cdot \mathrm{kg}^{-1}$ i.v., $\mathrm{n}=5$ ), and FK224 and indomethacin $\left(5 \mathrm{mg} \cdot \mathrm{kg}^{-1}\right.$ i.v. for each, $\left.\mathrm{n}=5\right)$. Data are expressed as mean \pm sEM. *: $\mathrm{p}<0.05$ compared with the values of control group; **: p $<0.01$ compared with the values of FK group. —— — : Control group; - - $\bullet \cdots \cdots-$ : FK group; ----n--- : FK+indomethacin group. DMSO: dimethyl sulphoxide; Bk: bradykinin. 


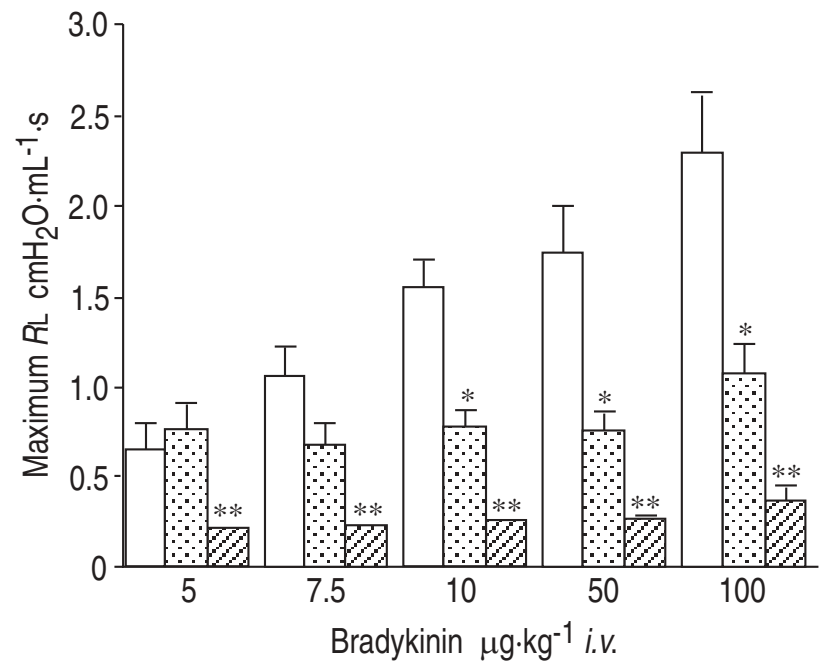

Fig. 2. - Dose-response curves to i.v. bradykinin $(5,7.5,10,50$ or $\left.100 \mu \mathrm{g} \cdot \mathrm{kg}^{-1}\right)$. Magnitudes of bronchoconstriction are expressed as maximum pulmonary resistance $(R \mathrm{~L})$ values. Pretreatment with DMSO (Control group: $0.2 \mathrm{~mL} \cdot \mathrm{kg}^{-1}$ i.v., $\mathrm{n}=5$ for each dose of Bk), FK224 (FK group: $5 \mathrm{mg} \cdot \mathrm{kg}^{-1}$ i.v., $\mathrm{n}=5$ for each dose of Bk), and FK224 and indomethacin $\left(5 \mathrm{mg} \cdot \mathrm{kg}^{-1}\right.$ i.v. for each $\mathrm{n}=5$ for each dose of Bk). Data are expressed as mean \pm SEM. $*$ : $\mathrm{p}<0.05$ compared with the values of control group; **: $\mathrm{p}<0.01$ compared with the values of FK group. $\square$ : Control group; $\square$ :FK group; $\square$ : FK+indomethacin group. DMSO: dimethyl sulphoxide; Bk: bradykinin.

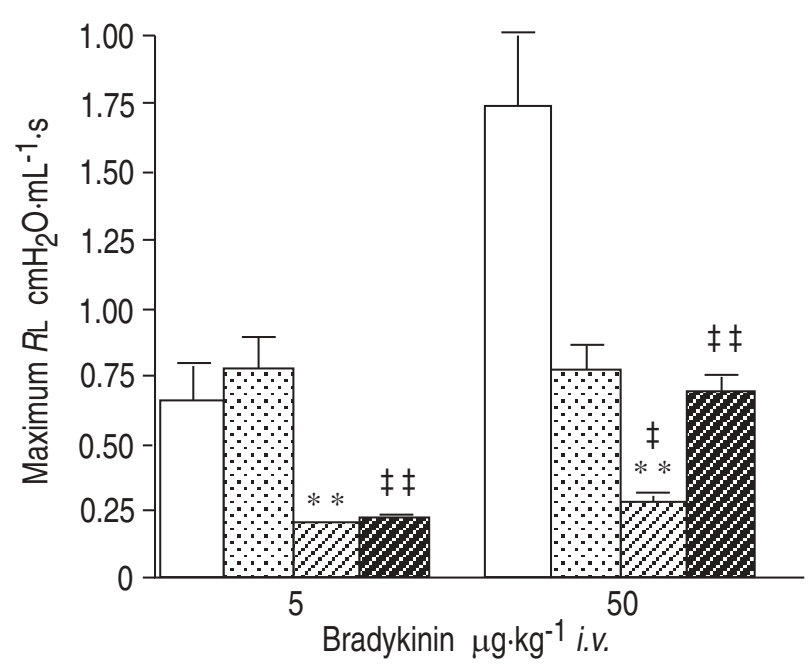

Fig. 3. - Dose-response curves to i.v. bradykinin (5 or $\left.50 \mu \mathrm{g} \cdot \mathrm{kg}^{-1}\right)$. Magnitudes of bronchoconstriction are expressed as maximum pulmonary resistance $(R \mathrm{~L})$ values. Pretreatment with DMSO (Control group: $0.2 \mathrm{~mL} \cdot \mathrm{kg}^{-1}$ i.v., $\mathrm{n}=5$ for each dose of $\mathrm{Bk}$ ), (FK group: $5 \mathrm{mg} \cdot \mathrm{kg}^{-1}$ i.v., $\mathrm{n}=5$ for each dose of $\mathrm{Bk}), \mathrm{FK} 224$ and indomethacin $\left(5 \mathrm{mg} \cdot \mathrm{kg}^{-1}\right.$ i.v. for each, $\mathrm{n}=5$ for each dose of $\mathrm{Bk}$ ), and DMSO and indomethacin ( $5 \mathrm{mg} \cdot \mathrm{kg}^{-1}$ i.v., $\mathrm{n}=5$ for each dose of $\mathrm{Bk}$ ). Data are expressed as mean \pm SEM. $* *: p<0.01$ compared with the value of FK group; $\ddagger: p<0.01$

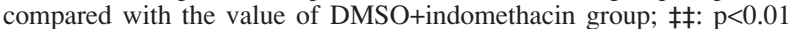
compared with the value of Control group. $\square$ : Control group; $\square$ : FK group; $\square$ : FK+indomethacin group; $\square$ : DMSO+indomethacin group. DMSO: dimethyl sulphoxide; Bk: bradykinin.

with indomethacin and DMSO also inhibited the increase in $R \mathrm{~L}$ at both low $\left(5 \mu \mathrm{g} \cdot \mathrm{kg}^{-1}\right)$ and high $\left(50 \mu \mathrm{g} \cdot \mathrm{kg}^{-1}\right)$ doses of $\mathrm{Bk}$ as compared to control, the reduction in $R \mathrm{~L}$ by a combination of indomethacin and FK224 was significantly greater than by indomethacin alone when a high dose of $\mathrm{Bk}\left(50 \mu \mathrm{g} \cdot \mathrm{kg}^{-1}\right)$ was administered $(\mathrm{p}<0.01)$.

\section{Discussion}

In the present study, we observed that bronchoconstriction induced via intravenous administration of a high dose of Bk was mediated by tachykinins and cyclo-oxygenase products, whilst a low dose of Bk induced bronchoconstriction by cyclo-oxygenase products. FK224, a novel tachykinin receptor antagonist (selective both for neurokinin-1 and neurokinin-2 receptors), significantly attenuated the bronchoconstriction induced by intravenous administrations of higher doses $\left(10,50\right.$ or $\left.100 \mu \mathrm{g} \cdot \mathrm{kg}^{-1}\right)$ of $\mathrm{Bk}$ in anaesthetized, mechanically-ventilated guineapigs. However, the bronchoconstriction induced by lower doses $\left(5\right.$ or $\left.7.5 \mu \mathrm{g} \cdot \mathrm{kg}^{-1}\right)$ of Bk was not affected. In addition, although pretreatment with indomethacin alone significantly reduced bronchoconstriction by a high dose of Bk $\left(50 \mu \mathrm{g} \cdot \mathrm{kg}^{-1}\right)$, pretreatment with both FK224 and indomethacin markedly inhibited the bronchoconstriction.

There have been several studies concerning the effects of Bk on airways in vivo. Some have shown that the direct administration of $\mathrm{Bk}$ into the airway lumen may cause bronchoconstriction through cholinergic mechanisms [9], or a direct effect on the smooth muscle [22], or the release of tachykinins from C-fibres [17, 23]. Although intravenous administration of $\mathrm{Bk}$ also induced bronchoconstriction by cholinergic mechanisms [24] and by a direct effect on the smooth muscle [25, 26], other studies have shown that it caused the release of cyclo-oxygenese products $[17,27]$. In the present study, cholinergic mechanisms were not contributing to the response because all animals were pretreated with atropine.

However, there are no studies showing that tachykinins contribute to the bronchoconstriction induced by intravenous administration of bradykinin. A previous study with capsaicin pretreatment showed that tachykinins did not appear to play a role in bronchoconstriction induced by intravenously administered bradykinin [17]. The study with CP-96,345, a neurokinin-1 receptor antagonist, showed that bronchoconstriction induced by i.v. Bk (15 nmol. $\mathrm{kg}^{-1}$, i.e. about $15 \mu \mathrm{g} \cdot \mathrm{kg}^{-1}$ ) was not mediated by activation of the neurokinin-1 receptor [18].

Possible reasons for the different findings between the present study and previous studies might be due to the method of investigation. Instead of using capsaicin for desensitization of C-fibres as in the previous study, we used FK224, a novel tachykinin receptor antagonist. Capsaicin releases several neuropeptides (neuropeptide $\mathrm{Y}$, vasoactive intestinal polypeptide, peptide histidine isoleucine, substance $\mathrm{P}$, neurokinin $\mathrm{A}$, calcitonin-generelated peptide, galamin) in the respiratory tree [28], which could affect bronchoconstriction and, therefore, the results of the experiment. To clarify the role of tachykinins more precisely, we used FK224 because it exhibits a dual inhibitory effect on neurokinin-1 and neurokinin-2 receptors $[19,20]$. Neurokinin-1 receptors have a preferential affinity for substance $\mathrm{P}$ and lesser affinity for other tachykinins, such as neurokinin A [29]; and neurokinin2 receptors have a preferential affinity for neurokinin A. FK224 inhibits bronchoconstriction induced by substance $\mathrm{P}$ or neurokinin A, but it does not affect contraction mediated by histamine and acetylcholine in guinea-pig in vitro and in vivo $[19,20]$. Airway oedema induced by substance $\mathrm{P}$ and neurokinin $\mathrm{A}$ is also reduced by FK224 
[20]. The contractile response to neurokinin A and substance $\mathrm{P}$ was not affected by atropine or indomethacin [30]. Moreover, ICHINOSE et al. [17] reported that FK224 inhibited bronchoconstriction induced by inhalation of Bk in asthmatic patients and suggested that tachykinins released from the airway sensory nerves are involved in response to inhaled $\mathrm{Bk}$.

Therefore, our results suggest that higher concentrations of intravenously administered Bk induce bronchoconstriction by escaping from degradation by pulmonary endothelial cells and, consequently, release tachykinins, such as substance $\mathrm{P}$ and neurokinin $\mathrm{A}$. The guinea-pig trachea contains receptors for neurokinin $\mathrm{A}$, a potent stimulant of airway smooth muscle [31], and for substance $\mathrm{P}$, which induces protein extravasation in the tracheal mucosa [32] as well as bronchoconstriction [18]. Thus, neurokinin A, which may be released predominantly by a high dose of intravenously administered Bk may induce bronchoconstriction. It is also possible that microvascular leakage could contribute to airway narrowing by the release of substance P. Because FK224 is a neurokinin receptor antagonist exhibiting a dual inhibitory effect on neurokinin-1 and neurokinin-2 receptors both in vitro and in vivo, and since another study has shown no involvement of neurokinin-1 receptors [18], it is possible that the neurokinin-2 receptor is involved in the bronchoconstriction induced by higher doses of $\mathrm{Bk}$ in the present study. To clarify the involvement of neurokinin-2 receptors precisely, further studies with a specific neurokinin-2 receptor antagonist will be needed.

As it has been reported that allergens increase bronchovascular permeability in the airways of human subjects with allergic asthma [7] and that asthmatic patients have an elevated concentration of kinin in their plasma [6], it seems likely that a concentration of Bk high enough to cause bronchoconstriction may gain access to airway C-fibres by diffusing from the plasma.

The present results are consistent with previous reports, which showed that low i.v. doses of Bk induced bronchoconstriction largely through the release of cyclooxygenase products. However, our data shows that higher doses of $i . v$. Bk can induce bronchoconstriction not only via cyclo-oxygenase products but also via tachykinin release.

In conclusion, high doses of intravenously administered bradykinin cause bronchoconstriction through the release of tachykinins and cyclo-oxygenase products. These results suggest the importance of a high concentration of plasma bradykinin in C-fibre stimulation in the pathogenesis of severe asthma attacks.

\section{References}

1. Regoli D, Barabe J. Pharmacology of bradykinin and related kinins. Pharmacol Rev 1980; 32: 1-46.

2. Proud D, Kaplan AP. Kinin formation: mechanisms and role in inflammatory disorders. Аппи Rev Immunol 1988; 6: 49-83.

3. Proud D, Macglashan DW, Newball HH, Shulmans A, Lichtenstein LM. Immunoglobulin E-mediated release of a kininogenase from purified human lung mast cells. Am Rev Respir Dis 1985; 132: 405-406.

4. Dusser DJ, Nadel JA, Sekizawa K, Graf PD, Borson DB. Neutral endopeptidase and angiotensin-converting enzyme inhibitors potentiate kinin-induced contraction of ferret trachea. J Pharmacol Exp Ther 1988; 244: 531-536.

5. Lotvall JO, Tokuyama K, Barnes P, Chung KF. Bradykinininduced airway microvascular leakage is potentiated by captopril and phosphoramidon. Eur J Pharmacol 1991; 200: 211-217.

6. Abe K, Watanabe N, Kumagai N, Mouri T, Seki T, Yoshinaga K. Circulating plasma kinin in patients with bronchial asthma. Experientia (Basel) 1967; 23: 626-627.

7. Christiansen SC, Proud D, Cochrane CG. Detection of tissue kallikrein in the bronchoalveolar lavage fluid of asthmatic subjects. J Clin Invest 1987; 79: 188-197.

8. Frossard N, Stretton CD, Barnes PJ. Mechanism of epithelial modulation of bradykinin responses in airway smooth muscle. Am Rev Respir Dis 1989; 139: A351.

9. Fuller RW, Dixon CMS, Cuss FMC, Barnes PJ. Bradykinininduced bronchoconstriction in humans. Am Rev Respir Dis 1987; 135: 176-180.

10. Simonsson BG, Skoogh BE, Bergh NP, Anderson R, Svedmyr N. In vivo and in vitro effects of bradykinin on bronchial motor tone in normal subjects and patients with airways obstruction. Respiration 1973; 30: 378388 .

11. Newball HH, Keiser HR. Relative effects of bradykinin and histamine on the respiratory system in man. J Appl Physiol 1973; 35: 552-556.

12. Newball HH, Keiser HR, Pisano JJ. Bradykinin and human airways. Respir Physiol 1975; 24: 139-146.

13. Kaufman MP, Coleridge HM, Coleridge JCG, Baker DG. Bradykinin stimulates afferent vagal C-fibers in intrapulmonary airways of dogs. $J$ Appl Physiol: Respirat Environ Exercise Physiol 1980; 48: 511-517.

14. Ray NJ, Jones AJ, Keen P. Morphine, but not sodium cromoglycate, modulates the release of substance P from capsaicin-sensitive neurones in the rat trachea in vitro. Br J Pharmacol 1991; 102: 797-800.

15. Saria A, Martling CR, Yan Z, Theodorsson-Northeim E, Camse R, Lundberg JM. Release of multiple tachykinins from capsaicin-sensitive sensory nerves in the lung by bradykinin, histamine, dimethylphenyl piperazinium, and vagal nerve stimulation. Am Rev Respir Dis 1988; 137: 1330-1335.

16. Inoue H, Koto H, Taketa S, Aizawa H, Ikeda T. Excitatory role of axon reflex in bradykinin-induced contraction of guinea pig tracheal smooth muscle. Am Rev Respir Dis 1992; 146: 1548-1552.

17. Ichinose M, Belvisi MG, Barnes PJ. Bradykinin-induced bronchoconstriction in guinea-pig in vivo: role of neural mechanism. J Pharmacol Exp Ther 1990; 253: 594-599.

18. Sakamoto T, Barnes PJ, Chung KF. Effect of CP-96,345, a nonpeptide NK-1 receptor antagonist, against substance P-, bradykinin- and allergen-induced airway microvascular leakage and bronchoconstriction in guinea-pig. Eur J Pharmacol 1993; 231: 31-38.

19. Morimoto M, Murai M, Maeda Y, et al. FK224, a novel cyclopeptide substance $\mathrm{P}$ antagonist with $\mathrm{NK}_{1}$ and $\mathrm{NK}_{2}$ receptor selectivity. J Pharmacol Exp Ther 1992; 262: 398-402.

20. Murai M, Morimoto H, Maeda Y, Kiyotoh S, Nishikawa M, Fujii T. Effects of FK224, a novel compound $\mathrm{NK}_{1}$ and $\mathrm{NK}_{2}$ receptor antagonist, on airway contriction and airway edema induced by neurokinins and sensory nerve stimulation in guinea-pigs. J Pharmacol Exp Ther 1992; 262: 403-408.

21. Sorkness R, Blythe S, Lemanske RF Jr. Pulmonary antigen challenge in rats passively sensitized with a monoclonal IgE antibody induces immediate but not late changes 
in airway mechanics. Am Rev Respir Dis 1988; 138: 1152-1156.

22. Abraham WM, Ahmed A, Chortes A, et al. Airway effects of inhaled bradykinin, substanse $\mathrm{P}$, and neurokinin A in sheep. J Allergy Clin Immunol 1991; 87: 557-564.

23. Ichinose $\mathrm{M}$, Nakajima $\mathrm{N}$, Takahashi $\mathrm{T}$, Yamauchi $\mathrm{H}$, Inoue $\mathrm{H}$, Takashima $\mathrm{T}$. Protection against bradykinininduced bronchoconstriction in asthmatic patients by neurokinin receptor antagonist. Lancet 1992; 340: 1248-1251.

24. Drazem JM, Austen KF. Atropine modification of the pulmonary effects of chemical mediators in the guineapig. J Appl Physiol 1975; 38: 834-838.

25. Farmer SG, Burch RM, Meeker SA, Wilkins DE. Evidence for a pulmonary $\mathrm{B}_{3}$ bradykinin receptor. Mol Pharmacol 1989; 36: 1-8.

26. Jln LS, Seeds E, Page CP, Schachter M. Inhibition of bradykinin-induced bronchoconstriction in the guinea-pig by a synthetic $\beta_{2}$-receptor antagonist. $\mathrm{Br} J$ Pharmacol 1989; 97: 598-602.

27. Rossoni G, Omini C, Vigano T, Mandelli V, Folgo G, Berti F. Bronchoconstriction by histamine and bradykinin in guinea-pig: relationship to thromboxane generation and the effect of aspirin. Prostaglandins 1980;20: 547-557.

28. Uddman R, Sundler F. Neuropeptide in the airways: a review. Am Rev Respir Dis 1987; 136: S3-S8.

29. Regoli D, Drapeau S, Dion S, Couture R. New selective agonists for neurokinin receptors: pharmacological tools for receptor characterization. Trends Pharmacol Sci 1988; 9: 290.

30. Uchida K, Nomura A, Ohtsuka M, et al. Neurokinin A as a potent bronchoconstrictor. Am Rev Respir Dis 1987; 136: 718-721.

31. Martling CR, Theodorsson-Norheim E, Lundberg JM. Occurrence and effects of multiple tachykinins: substance $\mathrm{P}$, neurokinin $\mathrm{A}$, nueropeptide $\mathrm{K}$ in human lower airways. Life Sci 1987; 40: 1633-1643.

32. Lundberg JM, Saria A, Brodin E, Russell S, Folkers K. A substance $P$ antagonist inhibits vagally-induced increase in vascular permeability and bronchial smooth muscle contraction in guinea-pig. Proc Natl Acad Sci USA 1983; 80: $1120-1124$ 